\title{
TOLERANCE OF AR1 NEOTYPHODIUM ENDOPHYTE TO FUNGICIDES USED IN PERENNIAL RYEGRASS SEED PRODUCTION
}

\author{
M.P. ROLSTON ${ }^{1}$, W.J. ARCHIE ${ }^{1}$ and W.R. SIMPSON ${ }^{2}$ \\ ${ }^{1}$ Plant Breeding and Genomics, AgResearch Limited, PO Box 60 Lincoln \\ ${ }^{2}$ Plant Breeding and Genomics, AgResearch Limited, Private Bag 11008, \\ Palmerston North \\ Corresponding author : phil.rolston@agresearch.co.nz.
}

\begin{abstract}
Perennial ryegrass (Lolium perenne) with the elite new AR1 endophyte (Neotyphodium lolii strain AR1) was treated with fungicides used for stem rust (Puccina graminis) control during head emergence, flowering and seed development. Field trials were carried out over two seasons, evaluating triazole and strobilurin fungicides and mixtures of these two groups of fungicides, applied either one or two times (Trial 1) or two or three times (Trial 2). Seed yields were measured and endophyte viability tested with grow-out tests of freshly harvested seed. Seed yields were increased by 76 to $83 \%$ with double applications, but not by single applications of azoxystrobin and epoiconazole in Trial 1. In the second year (Trial 2) seed yields were increased by between 13 and $27 \%$ with triple applications of these two fungicides and their mixtures. Endophyte viability was not affected by any of the fungicide treatments.

Keywords: azoxystrobin, fungicides, Neotyphodium, ryegrass, seed yield.
\end{abstract}

\section{INTRODUCTION}

Fungicides are commonly used in perennial ryegrass (Lolium perenne) seed production, primarily for the control of stem rust (Puccina graminis) epidemics that occur most years during the reproductive development to seed maturation stages of crop development. The two main fungicide groups used on ryegrass seed crops are the DMI-triazole group and the newly developed strobilurin group. Stem rust commonly appears in grass seed crops in November (late spring), and epidemics progress during December as temperatures increase. Control usually involves two or three fungicide applications during the period from head emergence (mid November) to early flowering (early December). For crops of rust-susceptible turf ryegrass cultivars, or in years of severe epidemics, another fungicide application during seed maturation (late December) may also be required.

Grass/endophyte associations involve fungi that have co-evolved with their hosts and are capable of producing alkaloids that are feeding deterrents to a range of insect and other herbivores (Easton et al. 2001). AR1 endophyte (Neotyphodium lolii) has been inoculated into New Zealand perennial ryegrass cultivars. This artificial association does not produce the alkaloids lolitrem B and ergovaline that are detrimental to the performance of domestic livestock, but produces peramine, a deterrent to a number of insect pests, including Argentine stem weevil (Listronotus bonariensis).

Few papers report effects of foliar applied fungicides on endophyte. Fletcher and Harvey (1981) reported no effect of systemic fungicides on endophyte in plants. Propiconazole was the only one of seven fungicides shown to reduce endophyte when applied to seed of two ryegrass lines, but the chemical was applied at very high rates (Harvey et al. 1982). Myclobutanil and propiconazole applied once or twice at $125 \mathrm{~g} / \mathrm{ha}$ per application for stem rust control had no effect on endophyte 
hyphae number in the ryegrass leaf sheaths (Latch \& Christensen 1988). In this paper we report on trials that evaluated the tolerance of the new AR1 endophyte in perennial ryegrass to triazole and strobilurin fungicides applied to crops either two or three times at full label rates.

Trial 1

\section{MATERIALS AND METHODS}

The trial site was at Methven (latitude $43.6 \mathrm{~S}$; altitude $330 \mathrm{~m}$ asl) in perennial ryegrass cv. Grasslands Samson infected with AR1 and sown in March 1999. The crop was sown in $30 \mathrm{~cm}$ wide rows at $9.0 \mathrm{~kg}$ seed/ha and was not irrigated. Fungicide treatments and rates applied in the trial are shown in Table 1. The fungicides used and their active ingredient (ai) concentrations were azoxystrobin ( $250 \mathrm{~g}$ ai/litre; Amistar soluble concentrate); epoxiconazole (125 g ai/litre; Opus soluble concentrate); propiconazole (250 g ai/litre; Tilt EC emulsifiable concentrate); and tebuconizole (430 g ai/litre; Folicur soluble concentrate). The application times and growth stages for applications were mid head emergence and flowering, on 22 November and 13 December 1999, respectively. Fungicides were applied with a four-nozzle, $2 \mathrm{~m}$ wide boom at $250 \mathrm{kPa}$ in 250 litres water/ha. The trial design was a randomised block design with two replicates.

The trial was harvested when the crop had a seed moisture content of $40 \%$ on the day before the farmer cut for harvest. At harvest two samples, each three rows by $1.0 \mathrm{~m}$ (total $1.8 \mathrm{~m}^{2}$ ), were cut from each plot and air dried in hessian bags. Three weeks after harvest the seed was threshed and cleaned on a two-screen air cleaner, and the machine dressed seed yield was calculated. The cleaned seed was stored at $3^{\circ} \mathrm{C}$ and $30 \%$ relative humidity until it was tested for endophyte. Viable endophyte was determined by grow-out tests using 40 seedlings per plot, harvested at 6 weeks after sowing and assayed using an immunological detection system called the "immuno-blot" test (Gwinn et al. 1991).

Trial 2

This trial, on the same farm with the same cultivar as in Trial 1, was sown on 30 March 2000 in $30 \mathrm{~cm}$ rows at $9 \mathrm{~kg}$ seed/ha. Nitrogen $(\mathrm{N})$ fertiliser was applied five times during winter and spring, giving a total of $235 \mathrm{~kg} \mathrm{~N} / \mathrm{ha}$. The plant growth regulator trinexapac-ethyl (Moddus) was applied at $150 \mathrm{~g} / \mathrm{ha}$ on 19 October. The fungicide treatments and rates are shown in Table 2. The trial was a randomised block design with four replicates. In addition to the fungicides used in Trial 1, two other fungicides were evaluated: carbendazim (Proteck $500 \mathrm{~g}$ ai $/ \mathrm{kg}$ ) and a strobilurin/triazole mix, kresoxim-methyl + epoxiconazole (Allegro 125+125 g ai/litre).

Plots received either nil, two or three fungicide applications. Applications were at mid-head emergence (Zadocks Growth Stage (GS) 55-57) on 30 November and peak flowering (14 December), while plots receiving three applications were also sprayed during seed maturation (31 December). The trial was harvested on the 8 January 2001 when the crop was at $40 \%$ seed moisture content. Grow-out tests for assessment of viable endophyte in harvested seed were based on 20 seedlings per plot.

\section{Seed Yield}

\section{RESULTS}

There was visually a low incidence of stem rust in the crops in both years. However, the best fungicide treatments increased seed yields by $83 \%$ in Trial 1 (a wet harvest season) and $27 \%$ in Trial 2 (a dry harvest season).

In Trial 1, two fungicides (azoxystrobin and epoxiconazole) when applied twice, resulted in an increase $(\mathrm{P}<0.05)$ in seed yield (Table 1). In Trial 2 mean seed yield for all fungicides and mixtures was increased $(\mathrm{P}<0.05)$ with three applications $(2170 \mathrm{~kg}$ seed $/ \mathrm{ha})$ compared to two applications $(1990 \mathrm{~kg} / \mathrm{ha})$, while two applications did not increase seed yield $(\mathrm{P}>0.05)$ compared with the nil fungicide treatment (1930 kg seed/ha). 
TABLE 1: Seed yield $(\mathrm{kg} / \mathrm{ha})$ and incidence of viable AR1 endophyte $(\mathbf{E} \%+)$ in ryegrass seed harvested from field plots treated with different fungicides in Trial 1 during 1999/2000.

\begin{tabular}{lcccc}
\hline & $\begin{array}{c}\text { Application rate } \\
\text { (g ai/ha) and timing }\end{array}$ & & \\
\cline { 2 - 3 } Fungicide & $\begin{array}{c}\text { Head } \\
\text { Emergence }\end{array}$ & Flowering & $\begin{array}{c}\text { Seed } \\
\text { yield }\end{array}$ & $\begin{array}{c}\text { Endophyte } \\
\text { incidence }\end{array}$ \\
\hline nil & 0 & 0 & 1230 & 98 \\
azoxystrobin & 0 & 188 & 1730 & 93 \\
& 0 & 250 & 1650 & 90 \\
& 0 & 376 & 1580 & 98 \\
& 188 & 188 & 2250 & 98 \\
tebuconazole & 190 & 250 & 1530 & 98 \\
& 0 & 0 & 1420 & 96 \\
epoxiconazole & 125 & 190 & 1440 & 95 \\
& 0 & 190 & 1550 & 99 \\
propiconazole & 125 & 125 & 1300 & 96 \\
& 0 & 125 & 1970 & 98 \\
& 125 & 125 & 1610 & 90 \\
& 0 & 125 & 1780 & 96 \\
& 0 & 180 & 1880 & 99 \\
LSD (P<0.05) & & 240 & 1280 & 95 \\
& 0 & 300 & 1850 & 96 \\
& & & 675 & 9 \\
\hline
\end{tabular}

${ }^{1}$ Head emergence application on 12 November 1999; Flowering application on 13 December 1999.

In Trial 2 the azoxystrobin + epoxiconazole treatment $(2300 \mathrm{~kg}$ seed $/ \mathrm{ha}$, mean of 2 and 3 applications) increased $(\mathrm{P}<0.05)$ seed yield compared with the nil fungicide treatment $(1930 \mathrm{~kg} / \mathrm{ha})$. The two components (azoxystrobin and epoxiconazole) as individual applications also resulted in significant seed yield increases for the triple, but not double application (Table 2). None of the other fungicides increased seed yield $(\mathrm{P}>0.05)$. No stem rust was recorded in the trial, and the 2000/01 year was generally a low pressure stem rust season, associated with a drier than average December (anthesis to seed maturity).

Endophyte infection

In both trials the fungicide treatments had no apparent effect on viable endophyte levels immediately after harvest (Tables 1 and 2). In all cases endophyte incidence in harvested seed was $90 \%$ or higher, even when higher than label rates of fungicide were applied with azoxystrobin and propiconazole. While some treatments have resulted in higher $(\mathrm{P}<0.05)$ endophyte levels than the control (Table 2$)$ no biological significance is attached to this small increase in endophyte incidence.

\section{DISCUSSION}

The fungicides evaluated in these trials represent the range of fungicides commonly used on ryegrass seed crops in New Zealand at the time the trials were carried out. As new fungicides become available to arable farmers and new endophytes are released onto the market, additional testing will need to be undertaken to ensure that new products do not adversely affect novel endophytes. Our trials indicate that, in the case of AR1 
TABLE 2: Seed yield (kg/ha) and incidence of viable AR1 endophyte $(E \%)$ in ryegrass seed harvested from field plots treated with two or three applications of different fungicides in Trial 2 during 2000/2001.

\begin{tabular}{|c|c|c|c|c|c|}
\hline \multirow[b]{2}{*}{ Fungicide } & \multicolumn{3}{|c|}{$\begin{array}{l}\text { Application rate (g ai/ha) } \\
\text { and timing }{ }^{1}\end{array}$} & \multirow[b]{2}{*}{$\begin{array}{l}\text { Seed } \\
\text { yield }\end{array}$} & \multirow[b]{2}{*}{$\begin{array}{l}\text { Endophyte } \\
\text { incidence }\end{array}$} \\
\hline & $\begin{array}{c}\text { Head } \\
\text { Emergence }\end{array}$ & Flowering & Seed fill & & \\
\hline nil & 0 & 0 & 0 & 1930 & 94 \\
\hline azoxystrobin & 250 & 250 & & 1730 & 100 \\
\hline & 250 & 250 & 250 & 2310 & 98 \\
\hline $\begin{array}{l}\text { kresoxım-methyl + } \\
\text { epoxiconazole }\end{array}$ & $\begin{array}{l}125+125 \\
125+125\end{array}$ & $\begin{array}{l}125+125 \\
125+125\end{array}$ & $125+125$ & $\begin{array}{l}1810 \\
2140\end{array}$ & $\begin{array}{l}98 \\
98\end{array}$ \\
\hline azoxystrobin + epoxiconazole & $\begin{array}{l}188+125 \\
188+125\end{array}$ & $\begin{array}{l}188+125 \\
188+125\end{array}$ & $188+125$ & $\begin{array}{l}2140 \\
2450\end{array}$ & $\begin{array}{c}100 \\
96\end{array}$ \\
\hline epoxiconazole & $\begin{array}{l}125 \\
125\end{array}$ & $\begin{array}{l}125 \\
125\end{array}$ & 125 & $\begin{array}{l}2160 \\
2190\end{array}$ & $\begin{array}{l}100 \\
99\end{array}$ \\
\hline tebuconazole & $\begin{array}{l}190 \\
190\end{array}$ & $\begin{array}{l}190 \\
190\end{array}$ & 190 & $\begin{array}{l}1920 \\
2010\end{array}$ & $\begin{array}{l}91 \\
99\end{array}$ \\
\hline carbendazim + tebuconazole & $\begin{array}{l}250+190 \\
250+190\end{array}$ & $\begin{array}{l}250+190 \\
250+190\end{array}$ & $250+190$ & $\begin{array}{l}2140 \\
2060\end{array}$ & $\begin{array}{c}100 \\
98\end{array}$ \\
\hline propiconazole & $\begin{array}{l}188 \\
188\end{array}$ & $\begin{array}{l}188 \\
188\end{array}$ & 188 & $\begin{array}{l}2020 \\
2070\end{array}$ & $\begin{array}{l}98 \\
98\end{array}$ \\
\hline $\operatorname{LSD}(\mathrm{P}<0.05)$ & & & & 240 & 4 \\
\hline
\end{tabular}

${ }^{1}$ Head emergence on 30 November; peak flowering on (14 December); seed maturation on (31 December)

endophyte in ryegrass, there is good tolerance to commonly used fungicides, including propiconazole at higher rates than the NZ registered rate of $125 \mathrm{~g}$ ai/ha. The azoxystrobin rates used in both of our trials included rates that are also higher than the registered use rate of $188 \mathrm{~g}$ ai/ha.

The seed yields achieved in these two trials were high. The response to fungicides in the two trials was not associated with stem rust control and was likely to be associated with reduced leaf senescence or higher green leaf areas and possible reduction in Ovularia pussilla (Rolston et al. 2000; McCloy et al. 2001). The small fungicide response reported in Trial 2 also occurred in another fungicide trial on forage ryegrass in the same year where similar low disease levels occurred (McCloy et al. 2001).

The immuno-blot test determines the presence or absence of endophyte but does not quantify hyphal density. Hyphal density, especially in seed embryos, may be critical for endophyte transmission in germinating seedlings. Additional research is required to measure whether the viability of endophyte during storage is influenced by pre-harvest fungicide treatments. Studies using accelerated ageing have been initiated on the samples from this trial to evaluate seed storage effects on endophyte viability.

It is concluded that the range of fungicides currently used on ryegrass seed crops has no effect on viable AR1 endophyte levels in harvested seed immediately after harvest.

\section{ACKNOWLEDGEMENTS}

Thanks to John Wright, Methven for providing the trial site; David Saville, AgResearch Lincoln, for statistical analysis; and Linda Reid for technical assistance. This research was funded by the Foundation for Research, Science and Technology (FRST) and FRST Non-specific output funding (NSOF) allocated by AgResearch. 


\section{REFERENCES}

Easton, H.S.; Christensen, M.J.; Eerens, J.P.J.; Fletcher, L.R.; Hume, D.E.; Keogh, R.G.; Lane, G.A.; Latch, G.C.M.; Pennell, C.G.L ; Popay, A.J.; Rolston, M.P.; Sutherland, B.L.; Tapper, B.A. 2001: Ryegrass endophyte: a New Zealand Grassland success story. Proc. N.Z. Grassland Assoc. 63:37-46.

Fletcher, L.R.; Harvey, I.C. 1981. An association of a Lolium endophyte with ryegrass staggers. NZ Vet. J. 10: 185-186.

Gwinn, K.D.; Collins-Shepard, M.H.; Reddick, B.B. 1991. Tissue print-immunoblot, an accurate method for the detection of Acremonium coenophialum in tall fescue. Phytopath. 81:747-748.

Harvey, I.C.; Fletcher, L.R.; Emms, L.M. 1982. Effects of several fungicides on the Lolium endophyte in ryegrass plants, seeds and in culture. N.Z. J. Agric. Res. 25: 601-606.

Latch, G.C.M.; Christensen, M.J. 1988. Effect of myclobutanil and propiconazole on endophyte and rust fungi in ryegrass. Proc. 41 st N.Z. Weed and Pest Control Conf.: 126-128.

McCloy, B.;Rolston, P.; Harvey, I. 2001. Fungicides, stem rust control in forage and turf ryegrass 2000/01. Foundation for Arable Research Report H00/05. Lincoln, N.Z.

Rolston, M.P.; Archie, W.; McCloy, B.; Harvey, I. 2000: Effects of fungicides on ryegrass seed yield. Foundation for Arable Research Report H99/15. Lincoln, N.Z. 